\title{
Contributions
}

Pınar Mine Güneş*

\section{The Impact of Female Education on Teenage Fertility: Evidence from Turkey}

DOI 10.1515/bejeap-2015-0059

Published online November 6, 2015

Abstract: This paper explores the causal relationship between female education and teenage fertility by exploiting a change in the compulsory schooling law (CSL) in Turkey. Using variation in the exposure to the CSL across cohorts and variation across provinces by the intensity of additional classrooms constructed in the birth provinces as an instrumental variable, the results indicate that primary school completion reduces teenage fertility by 0.37 births and the incidence of teenage childbearing by around 28 percentage points. Exploring heterogeneous effects indicates that female education reduces teenage fertility more in provinces with lower population density and higher agricultural activity. This paper also disentangles intensive- and extensive-margin effects and explores various channels, such as postponing marriage and contraceptive use, linking education and fertility. Finally, this paper demonstrates that there are additional social benefits of education in terms of child health.

Keywords: economic development, fertility, female education, compulsory schooling, instrumental variables, Turkey

JEL classification: I25, J13, 010

\section{Introduction}

Teenage childbearing adversely affects maternal and child well-being, including health, labor force participation, and earnings. ${ }^{1}$ Consequentially, reducing teenage childbearing is a key factor in achieving the Millennium Development Goals (MDGs) of reducing poverty, improving maternal health, and empowering women. Development economists and institutions have emphasized the role of female education in fertility, health, and human capital formation, and investment in

1 See Angrist and Evans, 2000; Chevalier and Viitanen, 2003; among others.

*Corresponding author: Pınar Mine Güneş, Department of Economics, University of Alberta, Edmonton, AB, Canada T6G 2H4, E-mail: gunes@ualberta.ca 
female education has been adopted as a development tool in many developing countries (Schultz 1993). However, a thorough understanding of the causal relationship between female education and teenage fertility has lagged behind the enthusiasm for educational interventions as a tool to reduce teenage childbearing.

This paper uses exposure to a nationwide reform of compulsory education system in 1997 in Turkey, which extended the basic educational requirement from 5 to 8 years (free of charge in public schools) as an instrumental variable (IV). The main objective of the compulsory schooling law (CSL) was to increase the education level to universal standards to enter the European Union. In order to accommodate the increased number of primary school students, additional classes and schools were constructed, new teachers were recruited, and transportation was arranged for children living in rural areas, who are often far away from existing schools. The CSL led to a significant increase in the number of students in primary school between the 1996/97 and the 2000/01 academic years, by around $21 \%$ from 8.65 million to 10.48 million. $^{2}$

This paper demonstrates that the CSL had a significant immediate effect on female education, thereby providing a useful instrument for evaluating the impact of schooling on teenage fertility. Using variation in the exposure to the CSL across cohorts and variation across provinces by the intensity of additional classrooms constructed in the birth-provinces as an IV, I show that female schooling reduces teenage fertility by around 0.37 births. More specifically, a 10 percentage-point increase in the probability of completing primary school ( 8 or more than 8 years of schooling) decreases fertility before 18 by around 44\%. Moreover, primary school completion reduces the probability of teenage motherhood by around 28 percentage points. Further, the results are robust to a rich set of controls. Moreover, female education reduces teenage fertility more in provinces with lower population density and higher agricultural activity. The results indicate that the reduction in fertility is primarily the consequence of a reduction in the probability of childbearing (extensive-margin effect), and the reduction in the probability of childbearing is primarily the consequence of a delay in childbearing within marriage. Finally, female education improves child health in terms of height-for-age (HAZ) and weight-for-age z-scores (WAZ), and the probability of stunting and being underweight.

The existing literature documents strong associations between education and child health and fertility, even after controlling for family and community background variables. (For a survey of the literature, see Strauss and Thomas, 1995.) However, the observed associations do not imply causality. Omitted variables (Berger and Leigh, 1989) - in particular ability (Griliches, 1977) and discount rates (Fuchs, 1982), which are highly correlated with both education and fertility

2 For educational statistics, see http://sgb.meb.gov.tr. 
decisions - may bias the relationship between education and fertility. Thus, studies treating education levels as exogenous fall short of answering the question of whether there is a causal relationship between education and fertility.

While there is a growing literature examining the causal effect of education on nonmarket outcomes, there are few studies examining the effect of education on fertility in developing countries. ${ }^{3}$ Breierova and Duflo (2004) examine the effect of a primary school construction program in Indonesia (INPRES) on child mortality and fertility, using the number of schools constructed in the region of birth and exposure across age cohorts induced by the timing of the program as IVs. Their results suggest that an additional year of average parental education reduces very early fertility (before the age of 15) by 0.01 births, whereas it is unimportant for early fertility (before the age of 25). Similarly, Osili and Long (2008) estimate the effect of female schooling on early fertility (before the age of 25) using exposure to an Universal Primary Education (UPE) program implemented for the non-Western regions of Nigeria. Using the state classroom construction funds per capita as a measure of program intensity, their results suggest that an additional year of education reduces early fertility by 0.26 births. Lavy and Zablotsky (2011) estimate the effect of women's education on fertility using exposure to the end of the military rule which restricted the mobility of Arabs in Israel, finding that women's education reduces completed fertility. Dinçer, Kaushal, and Grossman (2014) find a significant effect of education on the number of total pregnancies and total births per ever-married woman using a change in the CSL in Turkey as an instrument. ${ }^{4}$

3 In the context of a developed country, a number of studies have investigated the causal relationship between female education and fertility using various approaches and find mixed results. Using compulsory schooling laws, Black, Devereux, and Salvanes (2008) and Silles (2011) find that increased education reduces the incidence of teenage childbearing in the United States and Norway, and Great Britain and Northern Ireland, respectively. Using a German compulsory schooling reform, Cygan-Rehm and Maeder (2013) find that education reduces completed fertility. On the other hand, a few recent studies find insignificant effects of education on fertility using compulsory schooling laws in several European countries (see Monstad, Propper, and Salvanes, 2008 and Geruso, Clark, and Royer, 2011; among others). McCrary and Royer (2011) use age-at-school-entry policies in California and Texas and find that education does not affect fertility. Fort, Schneeweis, and Winter-Ebmer (2011) find a positive effect of education on fertility, using the schooling reforms in Europe.

4 While working independently and without knowledge of each other's work, Dinçer, Kaushal, and Grossman (2014) circulated a working paper around the same time a working paper for this paper was circulated. The primary contribution of this paper is to assess the impact of education on teenage fertility, which is a primary concern to improve maternal health and promote women empowerment. The empirical approaches are also dissimilar as Dinçer, Kaushal, and Grossman (2014) use the number of teachers in 12 regions and 20 subregions as the intensity of the CSL, while I use the number of additional classrooms in 80 provinces. 
This paper follows recent studies using IV and adds to the existing literature in several respects. ${ }^{5}$ The primary contribution is to explore the impact of female education on teenage fertility in a society lacking female empowerment and facing very high teenage fertility rates prior to the CSL. According to the World Economic Forum Global Gender Gap Report, the Middle East and North Africa (MENA) have the lowest regional ranking in comprehensive gender equality, highlighting the importance of understanding the role of education in reducing gaps in health and economic opportunities. In particular, Turkey is ranked far worse than countries previously studied and has a unique set of social and cultural institutions that have historically disadvantaged women. Focusing on teenage fertilities is particularly important in the context of Turkey because, while total fertility is close to the replacement fertility, teenage fertility was very high prior to the CSL. Following the CSL, teenage fertility declined by around $33 \%$ from the 1990s, suggesting that the policy might have significantly reduced teenage fertility.

Second, previous studies have investigated the impact of female education on fertility at markedly different points in the demographic transition; however, the role of policies is highly dependent on the stage of demographic transition. The case of Turkey provides an interesting case study because the policy intervention occurred at a later transition stage when the pace of fertility decline had slowed (starting from the early 1990s), which makes further reductions in fertility more difficult to achieve. Thus, this paper contributes to the literature by providing causal evidence that educational interventions can accelerate the demographic transitions at later stages.

Third, this paper contributes to the literature by uncovering the channels linking education and fertility, and exploring the spillovers of reduced fertility in terms of improvements in child health. Specifically, this paper demonstrates that both extensive (probability of childbearing)-and intensive (number of children conditional on childbearing)-margin effects are relevant channels in reducing fertility, but the extensive margin represents approximately $97 \%$ of the total effect. Moreover, the impact along the extensive margin is primarily driven by delayed childbearing within marriage, rather than postponing marriage.

5 Recent studies have used similar strategies to uncover the causal effect of schooling on different outcomes of nonmarket returns: for adult health, see van Kippersluis, O'Donnell, and van Doorslaer, 2011; Kenkel, Lillard, and Mathios, 2006; de Walque, 2007; Webbink, Martin, and Visscher, 2010; Grimard and Parent, 2007; Lleras-Muney, 2005; Silles, 2009; Clark and Royer, 2010; Kemptner, Jürges, and Reinhold, 2011; Albouy and Lequien, 2009; for child health, see Currie and Moretti, 2003; Lindeboom, Llena-Nozal, and Van der Klaauw 2009; McCrary and Royer, 2011; for political participation, see Borgonovi, d'Hombres, and Hoskins, 2010; for fertility, see footnote 4. 
Matching outcomes, on the other hand, is not an important factor in the role of education on fertility, while contraceptive use is an important potential factor. Finally, this paper demonstrates that there are additional social returns to education - primary school completion improves child health.

Fourth, this study explores heterogeneous effects across various dimensions, including pre-change levels of initial fertility and education, population density, urbanization, agricultural activity, and income in the province of birth as well as parental education. This understanding is crucial for understanding the effect of educational reforms on fertility as these dimensions vary significantly within developing countries. ${ }^{6}$

The remainder of this paper is organized as follows: Section 2 provides background on fertility, development, and the educational policy in Turkey; Section 3 describes the data; Section 4 describes the identification strategy and presents the empirical strategy and the results; and Section 5 concludes.

\section{Background}

This section discusses the conceptual framework and the background on education system in Turkey, and presents the trends in fertility and education prior to the change in the CSL. The CSL increased compulsory schooling from 5 to 8 years (free of charge in public schools) in 1997, with the objective of increasing education level to universal standards.

\subsection{Conceptual Framework}

Economic theory suggests several mechanisms through which education may influence fertility choices. One explanation is that education increases the returns to labor market participation, thereby increasing the opportunity cost of time-intensive activities (Becker, 1981; Schultz, 1981). As a result, women

6 This paper also contributes to the recent literature relying on the CSL to examine the impact of education on various outcomes. For example, Güneş (2015) finds that greater maternal education improves infant and child health, leads to earlier preventive care initiation, and reduces smoking. In a working paper, Cesur and Mocan (2013) find that education affects religiosity and voting behavior of women. In another working paper, Cesur, Dursun, and Mocan (2014) find that education does not affect self-reported health and body mass index (BMI). Finally, Kirdar, Tayfur, and Koç (2012) find that the CSL reduces the probability of getting married and giving birth at young ages using a hazard model. 
might substitute time-intensive activities, such as childbearing and child rearing, in order to devote more time to labor market participation. Also, education may affect fertility preferences - for instance, more educated women may prefer fewer but healthier (higher quality) children (Becker and Lewis, 1973). Improvements in child health resulting from female education may also reduce child mortality, thereby lowering fertility since fewer births are required to achieve the same family size (Lam and Duryea, 1999; Schultz, 1993). Education may reduce fertility through increased knowledge about contraceptives and the effective use of contraceptive methods (Rosenzweig and Schultz, 1985, 1989). In addition, education may increase women's autonomy and bargaining power in the household, increasing women's participation in fertility decision-making (Mason, 1986). Lastly, staying in school longer might postpone childbearing if having children impedes upon attending school.

While economic theory points to a number of mechanisms in which education influences fertility, the demography literature emphasizes that the relevance of these mechanisms is highly dependent on a country's stage of demographic transition. Changes in fertility behavior, including the adoption of birth control methods and preferences for smaller family size, caused by the spread of new ideas and information through mass media, family planning programs, etc., account for changes in the decline of the fertility rate in the early phase of the transition. However, as a country approaches the later stages of the transition, fertility becomes more closely tied to the level of socioeconomic development (Bongaarts, 2002). Further fertility declines, therefore, depend on improvements in socioeconomic conditions, particularly female education and child survival (Caldwell, 1980; Sen, 1999; Bongaarts, 2001). Therefore, increases in female education in demographic transitions may be linked to fertility declines at later stages.

\subsection{Trends in Fertility and Development in Turkey before the CSL}

Similar to many developing countries, Turkey has experienced a rapid fertility decline since the early 1960s, starting with a family planning program introduced in 1965, which legalized the sale and use of contraceptives. In 1980, Turkey implemented export-oriented policies, which increased the demand for labor in the service and industrial sectors, thereby reducing fertility. Moreover, the Population Planning Law in 1983 legalized induced abortions upon request for up to 10 weeks' gestation and allowed trained nurses and midwives to administer intrauterine device (IUDs). 
The traditional marriage pattern of Turkey is characterized by the universality of marriage: almost all women engage in either civil or religious marriages and childbearing out of wedlock is rare in Turkey. ${ }^{7}$ Hence, age at first birth depends on marriage age, which in turn affects overall fertility. Since the time interval between marriage and first birth has been stable with an average around 1.6 years in Turkey, a delay in marriage may result in an overall fertility decline by postponing first births. ${ }^{8}$

The total fertility rate (TFR) exceeded 6 children per woman in the early 1960s, dropped to 5 in the late 1970s, and dropped further to around 3 in the late 1980s. ${ }^{9}$ In the 1990s, fertility was around 2.6 births per woman (Figure 1), which is close to replacement fertility rate. On the other hand, adolescent fertility rate (births per 1,000 women ages 15-19) remained at around 60 (very high compared to many developed countries) during the 1990s. Following the CSL, TFR declined to around 2.4 births in 2003, while adolescent fertility rate declined to around 40 in $2003 .^{10}$

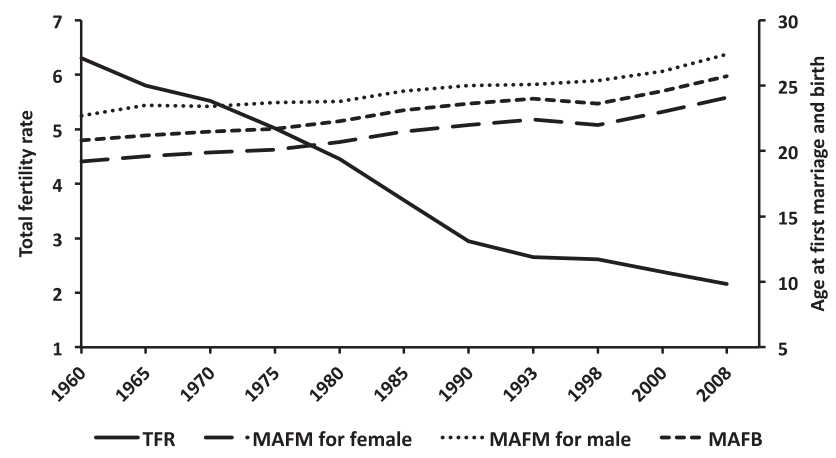

Figure 1: Total fertility rate (TFR) and mean age at first marriage and birth (MAFM and MAFB). Sources: TurkStat, Hacettepe University Institute of Population Studies (HUIPS).

It is also useful to look at changes in socioeconomic indicators in order to understand fertility trends, especially in the later stages of the transition. ${ }^{11}$ The gross domestic product (GDP) per capita almost doubled from 1980 to 1990;

72008 Turkey Demographic and Health Survey: http://www.hips.hacettepe.edu.tr.

8 The singulate mean age at marriage (the average number of years lived as never married before they get married for the first time among those who marry before age 50) for both sexes did not change (22 for females and 25 for males) over a period of 13 years from 1985 to 1998 (Figure 1). Thus, a delay in age at first marriage can play a crucial role in reducing fertility.

9 TFR is defined as the average number of children that would be born to a woman by the end of her childbearing period if she were to experience the exact current age-specific fertility rates. 10 Turkey Demographic and Health Survey Main Reports: http://www.hips.hacettepe.edu.tr. 11 For statistics related to socioeconomic indicators, http://www.turkstat.gov.tr. 
however, economic recessions were frequent during the 1990s (4 major crises took place in 1991, 1994, 1999, and 2001). Following the export-oriented reforms in the 1980s, the share of the population in urban areas rose from $44 \%$ in 1980 to $59 \%$ in 1990 , but did not significantly increase during the 1990 s (reaching $65 \%$ in early 2000). Despite improvements in infant and children under five mortality rates in the 1980s, both exceeded 55 per thousand live births during the first half of the 1990s, which is very high compared to developed countries. Adult literacy rates (the proportion of the adult population aged $15+$ which is literate) leveled off around 70 for females and 90 for males during the 1990s prior to the CSL. Hence, the CSL took place when many development indicators either leveled off or showed very little progress.

\subsection{Education and CSL in Turkey}

\subsubsection{Turkey's Education System}

Since 1923, the centralized Ministry of National Education (MONE) directs all educational related policy decisions, prepares the common curriculum of educational institutions, and monitors implementation in cooperation with provincial offices. ${ }^{12}$ Formal education in Turkey consists of pre-school, primary, secondary, and higher education. Prior to the law change in 1997, 5 years of primary education was compulsory for all citizens. In 1997, compulsory primary education was increased from 5 to 8 years. Following primary school, students may choose to attend one of the following secondary educational programs: general, vocational or technical high schools. The basic 8-year primary education level (public and private) gross enrollment rate is $107.58 \%$ in 32,797 schools with 503,328 teachers (Ministry of National Education 2011). ${ }^{13}$ As of 2010, there are more than 4.5 million students in secondary schools with a $93.34 \%$ gross enrollment rate.

\subsubsection{CSL and Trends in Education}

In 1997, the Turkish government took a "big bang" approach to education reform, increasing compulsory schooling from 5 to 8 years. ${ }^{14}$ The main objective

12 The Unification of Education Law no. 430 issued on 03.03.1924.

13 MONE calculates the gross enrollment rate by dividing the total number of students in a specific level of education by the population in the theoretical age group.

14 Compulsory education was extended to 8 years with the Basic Education Law no. 4306 dated 18.08.1997 as of the 1997/1998 Academic Year. 
of the 8-Year Basic Education Program was to increase the education level to universal standards to enter the European Union. In order to encourage compliance with the law, a new Primary School Diploma was awarded for only those completing the 8 th grade. ${ }^{15}$

Education is provided free of charge in public schools. The 8-Year Basic Education Program included construction of schools and classes and recruiting new primary school teachers in order to accommodate a greater number of students. The Program aimed at providing opportunities for all children to stay in school at least to the eighth grade. Thus, low-income students were provided free textbooks, school meals, and student uniforms. Moreover, transportation expenses to children living at least $2.5 \mathrm{~km}$ away from nearby village schools were covered under the Bussed Primary Education Scheme launched in the 1989/1990 Academic Year in order to improve access for children in rural areas. In addition, regional boarding primary schools (YIBO) were established to provide primary education services to settlements having no schools. ${ }^{16}$

58,726 additional classrooms were constructed within the first year of the change in the law (between the 1997/98 and the 1996/97 Academic Year), which corresponds to around a 30\% increase in the number of classrooms from the 1996/97 Academic Year and an average of around 10 additional classrooms per 1,000 primary school aged children in 1995 (data provided by the Turkish Statistics Institute).

While the Program aimed to extend educational opportunities to a greater share of the population, the qualitative components of the education system in general and the design of the curriculum in particular stayed the same. In an indepth case study prepared for the World Bank on the implementation of the 1997 Basic Education Law, Dulger (2004) attests that the Primary Education Program maintained the 1968 national curriculum with minor changes and that, due to time constraints in implementation, the MONE primarily focused on capacity issues to accommodate new students. Moreover, a 2007 OECD educational report emphasizes that the 1997 educational program in Turkey lacked implementation of a new curricula in order to improve the quality of the education system. ${ }^{17}$

The CSL had an impressive effect on enrollment rates of both sexes, especially on female enrollments in rural areas (female enrollment in rural areas in grade six increased significantly in the first year of the change in the law,

15 While the diploma provides an incentive for compliance with the law, there are no punitive legal consequences of non-compliance.

16 According to MONE, there were 687,056 children bussed to the primary schools, and 539 YIBO with 247,563 students in the 2010/2011 academic year.

17 Reviews of National Policies for Education: Basic Education in Turkey: http://www.oecd.org. 
roughly $162 \%) .{ }^{18}$ The net primary enrollment rate increased from 84.74 in the 1997/1998 Academic Year to 93.54 in the 1999/2000 Academic Year (Ministry of National Education, 2011). ${ }^{19}$ The increase in the net primary enrollment rate was greater for females than for males: 90.25 to 98.41 for males and 78.97 to 88.45 for females. The sex ratio in primary education rose from 85.63 to 88.54 .

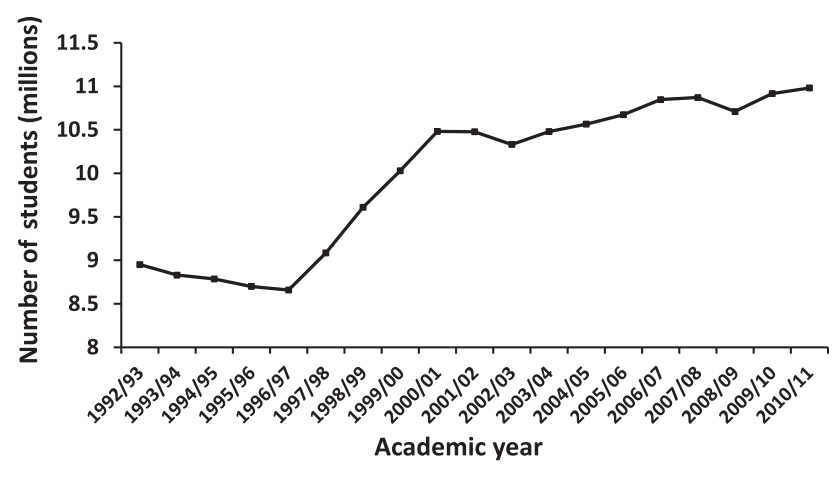

Figure 2: Number of students in 8-year primary education by academic year; enrollments in the 1992/93-1996/97 Academic Years prior to the change in the CSL are the sum of the number of students in the 5-year compulsory primary education and 3-year junior high school.

Figure 2 shows the trend in the number of students in basic education by academic year. The figure demonstrates that the CSL in 1997 had a significant effect on student primary school participation. Enrollments increased by around 15\% from 9.08 million in the 1997/98 Academic Year to 10.48 million in the 2000/ 01 Academic Year.

\section{Data}

The analyses are based on the 2008 Turkish Demographic and Health Survey (TDHS-2008). The TDHS survey is a demographic health survey conducted every 5 years by Hacettepe University Institute of Population Studies (HUIPS) since 1993. Of the 11,911 households surveyed in $2008,10,525$ were successfully

18 http://www.unicef.org/turkey/gr/ge21ja.html.

19 The net primary enrollment rate is calculated by dividing the number of students of a theoretical age group enrolled in a specific level of education by the population in that age group. 
interviewed, which yields an approximate response rate of 88\%. Among 10,525 interviewed households, 8,003 women were ever-married of reproductive ages at 15-49. The response rate for the ever-married sample is approximately $92 \%$.

The TDHS-2008 uses two types of questionnaires, the Household Questionnaire and the Individual Questionnaire. The latter targets ever-married women of reproductive ages (15-49), whereas the former targets all usual members of and visitors to the household. The nationally representative survey provides information on socioeconomic and demographic characteristics of a large number of women and contains a detailed fertility history of women surveyed with the Individual Questionnaire. $^{20}$ The TDHS-2008 data is appropriate for the purpose of this paper since it contains data on the education, year and province of birth, fertility, and marriage history of women. Appendix A presents summary statistics for women in the sample of analysis, which are between the ages of 18 and $30 .{ }^{21}$ The data include 4,537 women, of which 2,184 have children. ${ }^{22}$ The average level of completed schooling is 6.85 . The average fertility (the number of ever-born children) is 0.97 for the entire sample, 0.09 for fertility before the age of 18, 0.04 for fertility before the age of 17 , and 0.02 for fertility before the age of 16 .

Other data sources are the National Education Statistics books by MONE, Turkey's Statistical Year Books and detailed education data by Turkish Statistics Institute (TurkStat). The sources contain detailed information on enrollment rates in formal and non-formal education for both sexes, number of teachers, number of schools, and classes for different age groups in all provinces and for all academic years. ${ }^{23}$

20 Because childbearing is very rare outside of marriage, HUIPS does not record the fertility history of women that are not ever married. Comparing the TFR of the ever-married sample of women to the corresponding TFR of the population from birth records reported by TurkStat implies that less than one-half of $1 \%$ of births are to unmarried women. Consequently, the bias associated with restricting attention to the fertility history of ever-married women is likely to be modest.

21 The basis of sample selection is discussed under the identification section.

22 The TDHS-2008 contains information on whether a pregnancy has ever ended in a miscarriage, induced abortion, or a still birth; however, it does not provide the year of pregnancy termination, except for the latest pregnancy. Thus, I cannot determine whether or not the pregnancy was ended as a teenager. However, the results remain robust to the exclusion of such cases (618 women out of 4,537 for the sample of women ages 18-30).

23 Turkey is divided into five main regions: West, South, Central, North, and East. However, a new regional breakdown has been adopted from the European Union for statistical purposes as of 2002. Accordingly, there are 12 regions (NUTS I) with 81 provinces (Figure 3). I use mid-year population for the number of primary school age children in the province of birth (80 provinces) in 1995 (calculated using data from TUIK and MONE). 


\section{TURKEY - 12 REGIONS}
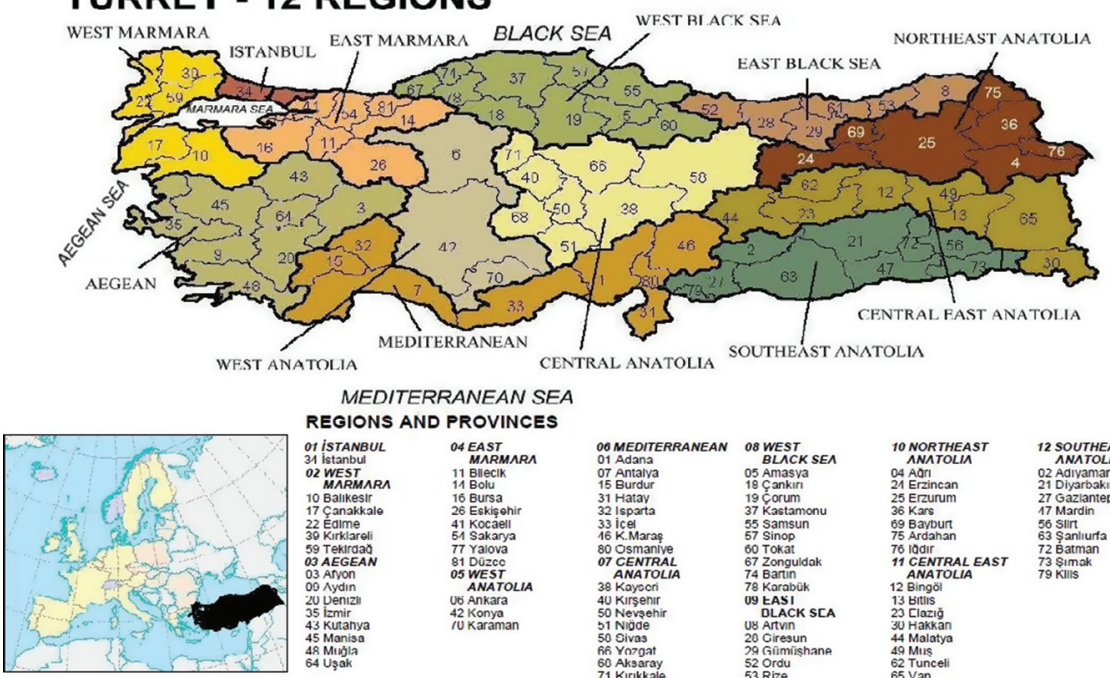

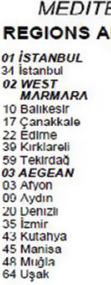
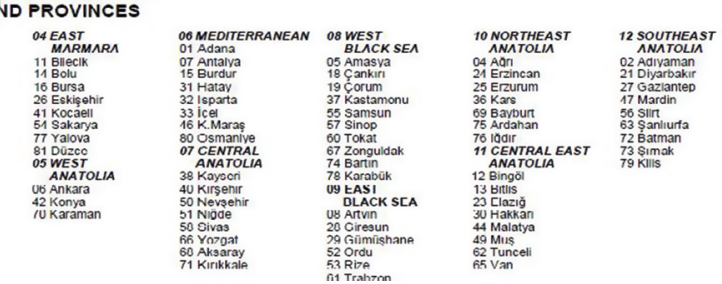

Figure 3: Administrative regions and provinces of Turkey.

Source: Turkey Demographic and Health Survey 2008 Main Report, Hacettepe University Institute of Population Studies, http://www.hips.hacettepe.edu.tr/eng/index.html.

\section{Empirical Methodology and Results}

Exposure to the CSL is determined by province and year (cohort) of birth. Cohorts aged 12 or older in 1997, when the CSL took place, had already graduated from primary school since Turkish children attend primary school between the ages of 7 and 11, and therefore are "unexposed" to the policy. ${ }^{24}$ On the other hand, cohorts aged 11 or younger in 1997 would be affected by the CSL and therefore are "exposed" to the policy. Variation in the exposure to the CSL across provinces is determined by the intensity of additional classrooms constructed in the provinces of birth. Because I use the 2008 TDHS data set, exposed cohorts are aged 18-22, while unexposed cohorts are aged 23 and older.

24 It is possible that some of these females might have been exposed to the policy because of grade repetition. However, there was not a high prevalence of them, and, moreover, results are robust to excluding these females. 


\subsection{Identification Strategy}

Identification follows from the generalized regression framework:

$$
E_{i j k}=a+\alpha_{1 j}+\beta_{1 k}+\text { ProvinceTrend }_{1 j k}+\left(\text { Intensity }_{j} \times T_{i}\right) y_{1}+X_{i j k}^{\prime} \theta_{1}+\varepsilon_{i j k}
$$

where $E_{i j k}$ is the education of an individual $i$, born in province $j$, in year $k, T_{i}$ is a dummy indicating whether individual $i$ is "exposed" to the policy, $a$ is a constant, $\alpha_{1 j}$ is a province-of-birth fixed effect, $\beta_{1 k}$ is a cohort-of-birth fixed effect, and ProvinceTrend ${ }_{1 j k}$ is a province-specific time trend. ${ }^{25}$ Intensity $_{j}$ is the number of additional classrooms per 1,000 primary school aged children in 1995 between the $1996 / 97$ and $1997 / 98$ Academic Year in each province. ${ }^{26} X_{i j k}^{\prime}$ is a vector of control variables, including controls for childhood environment (dummies indicating whether individual $i$ is Turkish, Kurdish, or others) and cohortof-birth-specific (time-varying) province-level variable (enrollment rates in 1995 interacted with cohort of birth dummies). ${ }^{27}$ In all specifications, I correct the standard errors for clustering at the province level. ${ }^{28}$

The following equation estimates the impact of female education on teenage fertility

$$
Y_{i j k}=a_{2}+\alpha_{2 j}+\beta_{2 k}+\text { ProvinceTrend }_{2 j k}+\pi E_{i j k}+X_{i j k}^{\prime} \theta_{2}+v_{i j k}
$$

where $Y_{i j k}$ is the number of children born before age 18 of a woman $i$, born in province $j$, in year $k^{29}$

Ordinary least squares (OLS) estimates of eq. [2] may be biased if schooling is correlated with unobserved factors, such as family background and personal traits. For instance, women with high discount rates of time or low ability levels are less likely to have higher education levels and more likely to become teenage parents. In order to identify the causal effect of female education on teenage fertility, a two-stage least squares (2SLS) methodology is implemented. ${ }^{30}$ The

25 For consistency with the literature, I use similar notation as Duflo (2001).

26 The results are similar using the number of teachers as a measure of province intensity of the reform as used by Dinçer, Kaushal, and Grossman (2014).

27 As an indicator of ethnicity, father's mother tongue categories are used. Specifications are robust to using mother's mother tongue categories.

28 Alternative levels of clustering, including clustering at the regional and subregional levels (12 and 20 clusters, respectively), clustering at the year of birth $\times$ province of birth levels, and two-way non-nested clustering (following Cameron, Gelbach, and Miller, 2006; and Thompson, 2011) yield similar results (see online Appendix).

29 Because the youngest women in the sample are aged 18, teenage fertility is defined as the number of children born before age 18 to circumvent the problem of censored fertility. The effect of female education on the number of children born before the ages of 17 and 16 are also explored. 30 The IV model is estimated using the command ivreg2 in STATA 11. 
interaction between the treatment dummy and the intensity measure is a valid instrument as exposure to the CSL should not directly affect fertility besides through changing educational attainment. ${ }^{31}$

In order to address the concern for differential time trends in fertility and education across provinces, specifications control for province-specific time trends. Province-of-birth fixed effects control for differences across provinces such as socioeconomic development and social norms. ${ }^{32}$ I also use cohort-ofbirth fixed effects to account for common trends in fertility.

Recall the exclusion restriction requires that the intensity of the reform should not directly affect the outcomes of interest, besides via changing schooling. In other words, the excluded instruments should be uncorrelated with the error term in (2). One particular concern is that the intensity of the reform is not random as the government likely devoted greater resources to provinces with a greater number of students taking up enrollment as a consequence of the reform. In order to capture any time-varying factors correlated with pre-program enrollment rates, the estimations control for enrollment rates in the province of birth in 1995 interacted with cohort of birth dummies. ${ }^{33}$

\subsection{Effect of the CSL on Education (First-Stage Estimation)}

The results for different specifications are presented in Table 1. Education is measured as a dummy variable indicating whether a female completed eight or more years of schooling (primary school completion). ${ }^{34}$ All specifications control for ethnicity, and cohort-of-birth and province-of-birth fixed effects. Column (2) controls for province-specific time trends, and column (3) adds enrollment rates in the province of birth in 1995 interacted with cohort of birth dummies. ${ }^{35}$ Finally,

31 The results are robust to using the treatment dummy as the instrument (see online Appendix).

32 There are 80 provinces included in the estimations based on the 1995 boundaries of Turkey. In all the estimations throughout the study, women born in Düzce are assumed to be born in Bolu since Düzce broke off Bolu and became a province in November 1999.

33 Enrollment rate is the number of children enrolled in primary school divided by the number of primary school age children in the province of birth in 1995 (80 provinces).

34 The estimated effect of the law on the number of years of education completed suggests that one additional classroom per 1,000 children increases female schooling by 0.03 years, which corresponds to an average increase of $0.28(0.03 \times 9.44)$. However, the $F$-statistic in the first stage is less than 10 , and consequently primary school completion is emphasized as a measure of female education.

35 To examine if the CSL succeeded in affecting targeted groups, the effects of the CSL on various levels of education are estimated: primary ( 5 years of education), primary after CSL (8 years), high (11 years of education), and advanced (11 + years of education). The effect of the 
Table 1: First-stage coefficients: Effects of the CSL on education.

\begin{tabular}{|c|c|c|c|c|}
\hline & \multicolumn{4}{|c|}{ Primary school completion } \\
\hline & (1) & (2) & (3) & (4) \\
\hline & $18-30$ & $18-30$ & $18-30$ & $\begin{array}{r}18-26 \\
\text { (exclude 22) }\end{array}$ \\
\hline $\begin{array}{l}\text { Treatment } \times \text { additional classrooms } \\
\text { per } 1,000 \text { children in province of birth }\end{array}$ & $\begin{array}{l}0.006^{\star \star \star} \\
(0.002)\end{array}$ & $\begin{array}{l}0.006^{\star \star \star} \\
(0.002)\end{array}$ & $\begin{array}{l}0.006^{\star * \star} \\
(0.002)\end{array}$ & $\begin{array}{l}0.007^{\star \star \star} \\
(0.002)\end{array}$ \\
\hline \multicolumn{5}{|l|}{ Control variables } \\
\hline Ethnicity & Yes & Yes & Yes & Yes \\
\hline Province-specific time trends & No & Yes & Yes & Yes \\
\hline Cohort of birth $\times$ enrollment rate & No & No & Yes & Yes \\
\hline F-statistics & 16.42 & 10.49 & 11.31 & 12.37 \\
\hline$R^{2}$ & 0.324 & 0.394 & 0.397 & 0.392 \\
\hline Observations & 4,537 & 4,537 & 4,537 & 2,899 \\
\hline
\end{tabular}

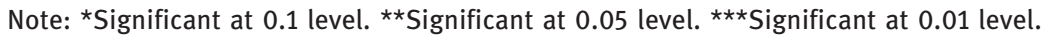

Dependent variable is a dummy variable indicating whether a female completed eight or more years of schooling (primary school completion). The $F$-statistics test the hypothesis that the coefficient of the interaction is zero. Standard errors (in parentheses) are adjusted for clustering on the province of birth. All specifications include respondent's cohort-of-birth and province-of-birth fixed effects.

column (4) restricts the sample to a tighter age window of 18-26 year old females $(27+$ are excluded), and excludes cohorts on the cusp of the reform (cohorts aged 11 in 1997) as they might not have benefitted from the reform due to early enrollment.

The estimated coefficients are all positive and statistically significant. The estimate of the increase in primary school completion due to the CSL is 0.006 . The results suggest that one additional classroom per 1,000 children increases primary school completion by 0.60 percentage points. The average number of additional classrooms per 1,000 children is 9.44, implying that the CSL increased primary school completion by 5.66 percentage points. This corresponds to around a $18 \%$ increase in primary school completion given that the average completion prior to the CSL is 32 percentage point (mean for unexposed cohort).

CSL is the highest for the probability of completing 8 years of education, which is the aim of the education policy. There is evidence that the CSL increased the likelihood of completing high school, and a negligible effect on the probability of completing advanced education. 
The $F$-statistics for the treatment dummy interacted with the intensity measure (excluded instrument) are reported in Table 1 . The $F$-statistics are all greater than $10 .^{36}$

Furthermore, I estimate the following equation to rule out the possibility of preexisting trends in education:

$$
E_{i j k}=a+\alpha_{1 j}+\beta_{1 k}+\text { ProvinceTrend }_{1 j k}+\sum_{l=7}^{18}\left(\text { Intensity }_{j} \times d_{i l}\right) y_{1 l}+X_{i j k}^{\prime} \theta_{1}+\varepsilon_{i j k}
$$

where $d_{i l}$ is a dummy indicating whether individual $i$ is age $l$ in 1997 (a cohort-ofbirth dummy). Females aged 19 in 1997 is the control group and hence this dummy is omitted from the regression. Recall, cohorts aged 12 and older in 1997 were not exposed to the CSL, implying that the coefficients of the interactions should be zero for these cohorts. Exposure to the CSL implies the coefficients $y_{11}$ should be significantly positive from $l=11$ to 7 . Figure 4 plots the coefficients of interactions. Each point on the solid line represents $y_{1 l}$ for each $l$. The pattern is consistent with the hypothesis that the change in compulsory schooling had no impact on the education of unexposed cohorts and had a positive effect on the education of the cohorts 11 and younger. The coefficients of the interactions are positive and significant for $l=7-11$, and close to 0 for $l=12-18$.

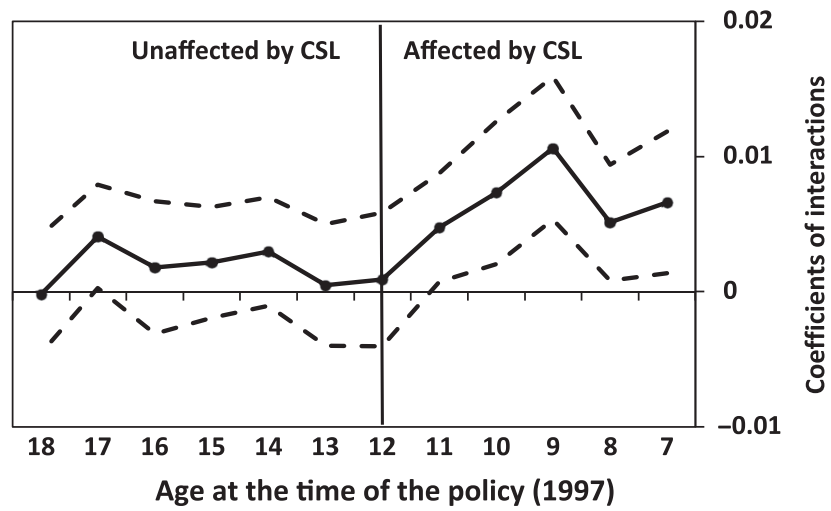

Figure 4: Coefficients of the interaction between the intensity measure and a dummy for age in 1997. The sample includes all females between the ages of 18 and 30 at the time of the survey. Females aged 12 in 1997 are the youngest unaffected cohort. Each point on the solid line represents the coefficient of the interaction between the intensity measure in birth-province and a dummy for age at the time of the policy. Dashed lines are $95 \%$ confidence intervals.

36 Critical F-statistic of 10 is suggested by Staiger and Stock (1997). Cameron and Trivedi (2005) use this rule of thumb, but they also propose a less strict rule of thumb of critical F-statistic of 5 . 


\subsubsection{Placebo Reforms}

While it is reassuring that exposure to the CSL increases education, it would also be reassuring that exposure to placebo reforms has non-significant effects on education. Towards this end, I compare the average education of women exposed and unexposed to the pseudo reforms based on their year of birth. Specifically, females aged 23-26, 27-30, and 31-34, at the time of the survey, are assigned to treated groups with respect to exposure to pseudo reforms, while corresponding females aged 27-30, 31-34, and 35-38, are assigned to control groups, in Panels A, $\mathrm{B}$, and $\mathrm{C}$, respectively. The estimated coefficients, reported in Table 2, suggest no significant effects of pseudo reforms on female education. The results therefore corroborate that the CSL had no effect on the education of unexposed cohorts.

Table 2: Pseudo-reform.

\begin{tabular}{lrrr}
\hline & \multicolumn{3}{c}{ Primary school completion } \\
\cline { 2 - 4 } & $(1)$ & $(2)$ & (3) \\
\hline Panel A: 23-26 (treatment) vs 27-30 (control) & 0.000 & 0.000 & 0.000 \\
& $(0.001)$ & $(0.003)$ & $(0.003)$ \\
Observations & 3,066 & 3,066 & 3,066 \\
Panel B: 27-30 (treatment) vs 31-34 (control) & 0.001 & 0.002 & 0.000 \\
& $(0.001)$ & $(0.003)$ & $(0.003)$ \\
Observations & 2,737 & 2,737 & 2,737 \\
Panel C: 31-34 (treatment) vs 35-38 (control) & 0.001 & 0.002 & 0.000 \\
& $(0.002)$ & $(0.003)$ & $(0.003)$ \\
Observations & 2,478 & 2,478 & 2,478 \\
Control variables & & & \\
Ethnicity & Yes & Yes & Yes \\
Province-specific time trends & No & Yes & Yes \\
Cohort of birth $\times$ enrollment rate & No & No & Yes \\
\hline
\end{tabular}

Note: All treatment and control groups are defined by age at the time of the survey. Standard errors (in parentheses) are adjusted for clustering on the province of birth. All specifications include respondent's cohort-of-birth and province-of-birth fixed effects.

\subsection{Effect of Female Schooling on Teenage Fertility}

Table 3 presents both OLS and IV estimates of the effect of female schooling on teenage fertility. Panels A, B, and C of Table 3 report estimates for fertility before age 18, age 17, and age 16, respectively. Columns (1) and (2) include females 
Table 3: Effects of female schooling on fertility outcomes: OLS and 2SLS estimates.

\begin{tabular}{|c|c|c|c|c|}
\hline & (1) & (2) & (3) & (4) \\
\hline & $18-30$ & $18-30$ & $18-30$ & $18-26$ \\
\hline \multicolumn{5}{|l|}{ Panel A: fertility before age 18} \\
\hline OLS & $\begin{array}{l}-0.095^{\star \star \star} \\
(0.012)\end{array}$ & $\begin{array}{l}-0.095^{\star \star \star} \\
(0.013)\end{array}$ & $\begin{array}{l}-0.093^{\star \star \star} \\
(0.013)\end{array}$ & $\begin{array}{l}-0.083^{\star \star \star} \\
(0.012)\end{array}$ \\
\hline $2 S L S$ & $\begin{array}{l}-0.348^{\star} \\
(0.204)\end{array}$ & $\begin{array}{l}-0.370^{\star} \\
(0.198)\end{array}$ & $\begin{array}{l}-0.347^{\star} \\
(0.204)\end{array}$ & $\begin{array}{l}-0.340^{\star} \\
(0.192)\end{array}$ \\
\hline$p$-value endogeneity test & 0.035 & 0.067 & 0.032 & 0.075 \\
\hline$p$-value underidentification test & 0.0003 & 0.0052 & 0.0002 & 0.0049 \\
\hline \multicolumn{5}{|l|}{ Panel B: fertility before age 17} \\
\hline OLS & $\begin{array}{l}-0.048^{\star * \star} \\
(0.009)\end{array}$ & $\begin{array}{l}-0.049^{\star \star \star} \\
(0.009)\end{array}$ & $\begin{array}{l}-0.047^{\star \star \star} \\
(0.009)\end{array}$ & $\begin{array}{l}-0.043^{\star \star \star} \\
(0.008)\end{array}$ \\
\hline $2 \mathrm{SLS}$ & $\begin{array}{l}-0.252^{\star \star} \\
(0.121)\end{array}$ & $\begin{array}{l}-0.240^{\star \star} \\
(0.120)\end{array}$ & $\begin{array}{l}-0.267^{\star \star} \\
(0.111)\end{array}$ & $\begin{array}{l}-0.208^{\star} \\
(0.108)\end{array}$ \\
\hline$p$-value endogeneity test & 0.075 & 0.082 & 0.100 & 0.090 \\
\hline$p$-value underidentification test & 0.0111 & 0.0157 & 0.0011 & 0.0056 \\
\hline \multicolumn{5}{|l|}{ Panel C: fertility before age 16} \\
\hline OLS & $\begin{array}{l}-0.020^{\star * *} \\
(0.004)\end{array}$ & $\begin{array}{l}-0.020^{\star \star \star} \\
(0.005)\end{array}$ & $\begin{array}{l}-0.020^{\star \star \star} \\
(0.005)\end{array}$ & $\begin{array}{l}-0.017^{\star \star \star} \\
(0.005)\end{array}$ \\
\hline $2 \mathrm{SLS}$ & $\begin{array}{l}-0.242^{\star \star} \\
(0.115)\end{array}$ & $\begin{array}{l}-0.218^{\star \star} \\
(0.107)\end{array}$ & $\begin{array}{l}-0.203^{\star \star} \\
(0.088)\end{array}$ & $\begin{array}{l}-0.165^{\star} \\
(0.089)\end{array}$ \\
\hline$p$-value endogeneity test & 0.066 & 0.093 & 0.063 & 0.056 \\
\hline$p$-value underidentification test & 0.0111 & 0.0113 & 0.0006 & 0.0099 \\
\hline Exclude 22 & No & No & Yes & Yes \\
\hline \multicolumn{5}{|l|}{ Control variables } \\
\hline Ethnicity & Yes & Yes & Yes & Yes \\
\hline Province-specific time trends & Yes & Yes & Yes & Yes \\
\hline Cohort of birth $\times$ enrollment rate & No & Yes & Yes & Yes \\
\hline Observations & 4,537 & 4,537 & 4,192 & 2,899 \\
\hline
\end{tabular}

Note: ${ }^{*}$ Significant at 0.1 level. ${ }^{*}$ Significant at 0.05 level. ${ }^{* \star *}$ Significant at 0.01 level. Standard errors (in parentheses) are adjusted for clustering on the province of birth. All specifications include cohort-of-birth and province-of-birth fixed effects.

aged 18-30, column (3) include females aged 18-30 excluding females aged 22, and column (4) includes females aged 18-26 excluding females aged 22.

The first row of Panel A displays the OLS estimates, indicating that primary school completion reduces the number of births before age 18 by 0.10 (significant at the $1 \%$ level). Thus, a 10 percentage-point increase in the probability of completing primary school reduces teenage fertility by $11 \%$ at the mean. The 
second row of Panel A presents the 2SLS results, indicating primary school completion reduces the number of births by 0.37 . Thus, a 10 percentage-point increase in the probability of completing primary school reduces fertility by around 0.04 , which corresponds to a reduction of $44 \%$ in teenage births at the mean.

Panels B and C report the OLS and 2SLS results for fertility before ages 17 and 16, respectively. The OLS estimates suggest that primary school completion reduces the number of births before 17 and 16 by 0.05 and 0.02 , while the 2SLS estimates suggest that primary school completion reduces the number of births before 17 and 16 by 0.24 and 0.22 .

The results are consistent excluding cohorts on the cusp of the reform (column 3), and using a tighter age window (column 4).

Table 3 reports the $p$-values of underidentification (Anderson canonical correlations test) and endogeneity tests (Hausman test). ${ }^{37}$

For all measures of teenage fertility, the IV estimates exceed the OLS estimates, suggesting that the OLS estimates may be biased downwards due to omitted variables that correlate with both higher levels of schooling and early child rearing, such as access to economic opportunities. Another possible explanation is that the IV estimates pertain to only a subsample of women whose educational attainment has been affected by the change in the CSL. The effect of education on fertility may be higher for this subsample, thereby leading to larger IV estimates compared to OLS estimates. The possibility of heterogeneous effects of education on teenage fertility is explored in Section 4.4.

Table 4 demonstrates that the effect of the CSL on fertility persists for later fertility (number of births before the ages of 19, 20, 21, and 22 - much beyond the ages above which the CSL binds). To assess fertility before various ages, treatment and control groups are defined to avoid censuring fertility. For example, for fertility before age 20, the treatment group is age 9-11 in 1997, whereas the control group is age 12-19 in 1997. As a robustness check, I use a tighter age window for the control group in Panel B. Panel A suggests that the CSL decreased fertility before age 20 and 21 by around 0.04 and 0.03 , which corresponds to a reduction of $15 \%$ and $8 \%$ at the mean, respectively. ${ }^{38}$

37 Because the model is exactly identified, an overidentification test cannot be performed. The underidentification tests reject the null hypothesis that the model is underidentified for all outcomes. The endogeneity tests reject the null hypothesis that female education may be treated as exogenous for all outcomes, except for column (3) in Panel B (Wooldridge, 2002).

38 The effects of the CSL on fertility before ages 20 and 21 are calculated by multiplying the average number of additional classrooms per 1,000 children with the coefficients in Table 4 $(0.004 \times 9.44=0.04$ and $0.003 \times 9.44=0.03$, respectively $)$. Reductions in terms of percents are calculated using the mean levels of fertility before ages 20 and 21 ( 0.26 and 0.37 , respectively). 
Table 4: Effect of the CSL on fertility.

\begin{tabular}{|c|c|c|c|c|}
\hline & \multicolumn{4}{|c|}{ Dependent variable } \\
\hline & Before 19 & Before 20 & Before 21 & Before 22 \\
\hline & (1) & (2) & (3) & (4) \\
\hline Panel A: treatment/control & $8-11 / 12-19$ & $9-11 / 12-19$ & $10-11 / 12-19$ & $11 / 12-19$ \\
\hline $\begin{array}{l}\text { Treatment } \times \text { additional } \\
\text { classrooms }\end{array}$ & $-0.003^{\star \star}$ & $-0.004^{\star \star}$ & $-0.003^{\star}$ & $-0.005^{\star \star}$ \\
\hline $\begin{array}{l}\text { per } 1,000 \text { children in province } \\
\text { of birth }\end{array}$ & $(0.001)$ & $(0.002)$ & $(0.002)$ & $(0.002)$ \\
\hline Observations & 4,077 & 3,684 & 3,274 & 2,962 \\
\hline Panel B: treatment/control & $8-11 / 12-14$ & $9-11 / 12-14$ & $10-11 / 12-14$ & $11 / 12-14$ \\
\hline $\begin{array}{l}\text { Treatment } \times \text { additional } \\
\text { classrooms }\end{array}$ & $-0.002^{\star}$ & $-0.004^{\star}$ & $-0.003^{*}$ & -0.005 \\
\hline $\begin{array}{l}\text { per } 1,000 \text { children in province } \\
\text { of birth }\end{array}$ & $(0.001)$ & $(0.002)$ & $(0.002)$ & $(0.003)$ \\
\hline Observations & 2466 & 2073 & 1663 & 1351 \\
\hline
\end{tabular}

Note: All treatment and control groups are defined by age in 1997. Standard errors (in parentheses) are adjusted for clustering on the province of birth. All specifications include cohort-of-birth and province-of-birth fixed effects, respondent's ethnicity, province-specific time trends, and enrollment rates in the province of birth interacted with cohort of birth dummies.

\subsection{Are There Heterogeneous Effects?}

The effect of the CSL on education and the effect of education on fertility are likely to depend on multiple characteristics. Uncovering heterogeneous effects has important policy implications both in understanding the expected outcomes and for designing optimal policy interventions. To examine whether there are heterogeneous effects, I split the sample into various subsamples by birth-province and parental education, and use the specifications that include all controls.

\subsubsection{Parental Education and Pre-change Levels of Education and Fertility in the Province of Birth}

I test for heterogeneity by parental education by dividing the sample into females with mothers (i) not completing primary school and (ii) completing at least primary school. ${ }^{39}$ Columns (1) and (2) of Table 5 demonstrate that the CSL

39 Approximately half of the females in the sample have mothers completing at least primary school. The results are similar using father's education. 
Table 5: Heterogeneity by parental education and pre-change levels of fertility and education.

\begin{tabular}{|c|c|c|c|c|c|c|}
\hline & \multicolumn{2}{|c|}{ Parental education } & \multicolumn{4}{|c|}{ Pre-change province-of birth characteristics } \\
\hline & \multirow{2}{*}{$\begin{array}{r}\text { No } \\
\text { Primary }\end{array}$} & \multirow{2}{*}{$\begin{array}{l}\text { At least } \\
\text { Primary }\end{array}$} & \multicolumn{2}{|c|}{ Pre-change education } & \multicolumn{2}{|c|}{ Pre-change fertility } \\
\hline & & & $<$ Median & $\geq$ Median & $<$ Median & $\geq$ Median \\
\hline & (1) & (2) & (3) & (4) & (5) & (6) \\
\hline \multicolumn{7}{|l|}{ Effect of the CSL on education } \\
\hline $\begin{array}{l}\text { Treatmentxadditional } \\
\text { classrooms per 1,000 } \\
\text { children in province } \\
\text { of birth }\end{array}$ & $\begin{array}{l}0.007^{\star \star} \\
(0.003)\end{array}$ & $\begin{array}{l}0.005^{\star \star} \\
(0.002)\end{array}$ & $\begin{array}{l}0.011^{\star \star} \\
(0.004)\end{array}$ & $\begin{array}{l}0.011^{\star \star \star} \\
(0.004)\end{array}$ & $\begin{array}{l}0.007^{\star \star} \\
(0.003)\end{array}$ & $\begin{array}{c}0.008^{\star} \\
(0.005)\end{array}$ \\
\hline \multicolumn{7}{|c|}{ Impact of female education on fertility } \\
\hline Primary school completion & $\begin{array}{l}-0.354^{\star} \\
(0.200)\end{array}$ & $\begin{array}{l}-0.294^{\star} \\
(0.175)\end{array}$ & $\begin{array}{l}-0.437^{\star} \\
(0.262)\end{array}$ & $\begin{array}{l}-0.089 \\
(0.195)\end{array}$ & $\begin{array}{l}-0.284^{\star *} \\
(0.127)\end{array}$ & $\begin{array}{l}-0.474^{*} \\
(0.242)\end{array}$ \\
\hline
\end{tabular}

Note: *Significant at 0.1 level. **Significant at 0.05 level. ***Significant at 0.01 level.

Median pre-program education is 6.428 ; median pre-program fertility is 0.091 . Standard errors (in parentheses) are adjusted for clustering on the province of birth. All specifications include cohortof-birth and province-of-birth fixed effects, respondent's ethnicity, province-specific time trends, and enrollment rates in the province of birth interacted with cohort of birth dummies.

was more successful at increasing education of women with lower levels of parental education and the impact of education was higher for the same group; however, the differences are not statistically significant.

One hypothesis is that it is easier to increase education when the baseline level is lower and, similarly, to reduce fertility when the baseline level is higher (Barham, 2011). I explore heterogeneity of both the effect of female education on fertility and the effect of the CSL on education according to the baseline (prechange) levels of fertility and education by dividing the sample into provinces (by birth) with average fertility or education of the unexposed cohort above (or below) the sample median.

Table 5 (first row) suggests that the effect of the CSL on female education is higher in provinces where the initial levels were lower than the sample median; however, the difference is not statistically significant. Second, the impact of female education on teenage fertility (second row) is higher (lower) in provinces with initial fertility above (below) the median. Specifically, primary school completion reduces teenage fertility by 0.47 births in provinces with initial fertility above the median, compared to 0.28 births in provinces below the median. The results therefore indicate that there are heterogeneous effects by pre-fertility levels in birth-provinces. 


\subsubsection{Pre-change Characteristics of the Province of Birth}

Another possible source of heterogeneity is population density because females in sparsely populated provinces are more likely to be affected by the CSL, either as a consequence of new school constructions or more transportation services. Other possible sources of heterogeneity are income (GDP per capita), urbanization rates (the percentage of population in cities), and agricultural activity (percentage of households engaged in agricultural production). ${ }^{40}$

The results are reported in Table 6. The effect of the CSL on education (first row) is slightly higher in provinces with urbanization rates, income levels, and population densities below the median. In provinces with population densities, incomes, and urbanization rates below the median, the CSL increased primary school completion by around 7, 7, and 9 percentage points, respectively, compared to 6 percentage points in provinces above the median. However, the differences are not statistically significant. The impact of female education on teenage fertility (row 2) is higher in provinces with lower urbanization rates and incomes, compared to insignificant effects in provinces above the median. Primary school completion reduces teenage fertility by 0.70 births in provinces with population densities below the median, compared to 0.45 births in provinces above the median (the difference is significant at the $5 \%$ level). Finally, primary school completion reduces teenage fertility by 0.41 births in provinces with agricultural activity above the median, compared to an insignificant effect in provinces below the median.

\subsection{Exploring Additional Outcomes}

This sections aims to shed light on two related questions. First, why does education affect fertility? That is, what are the channels in which education affects fertility? Second, are there negative repercussions of early childbearing? That is, are there additional benefits, or spillovers, of increased education? Table 7 presents the results of the effect of female education on various outcomes.

The estimated effect of female education on fertility represents both extensive- and intensive-margin effects. Exploring whether education leads to less females becoming mothers (extensive margin), or mothers having less children (intensive margin), sheds light on why education affects fertility. Towards this

\footnotetext{
40 I use GDP per capita, population densities, and urbanization rates in 1990 (prior to CSL). However, I use agricultural activity in 2001 (the earliest data available at the province level is 2001) and assume that the percentage of households engaged in agricultural activity has not changed significantly over the 4 years since the change of the CSL in 1997.
} 


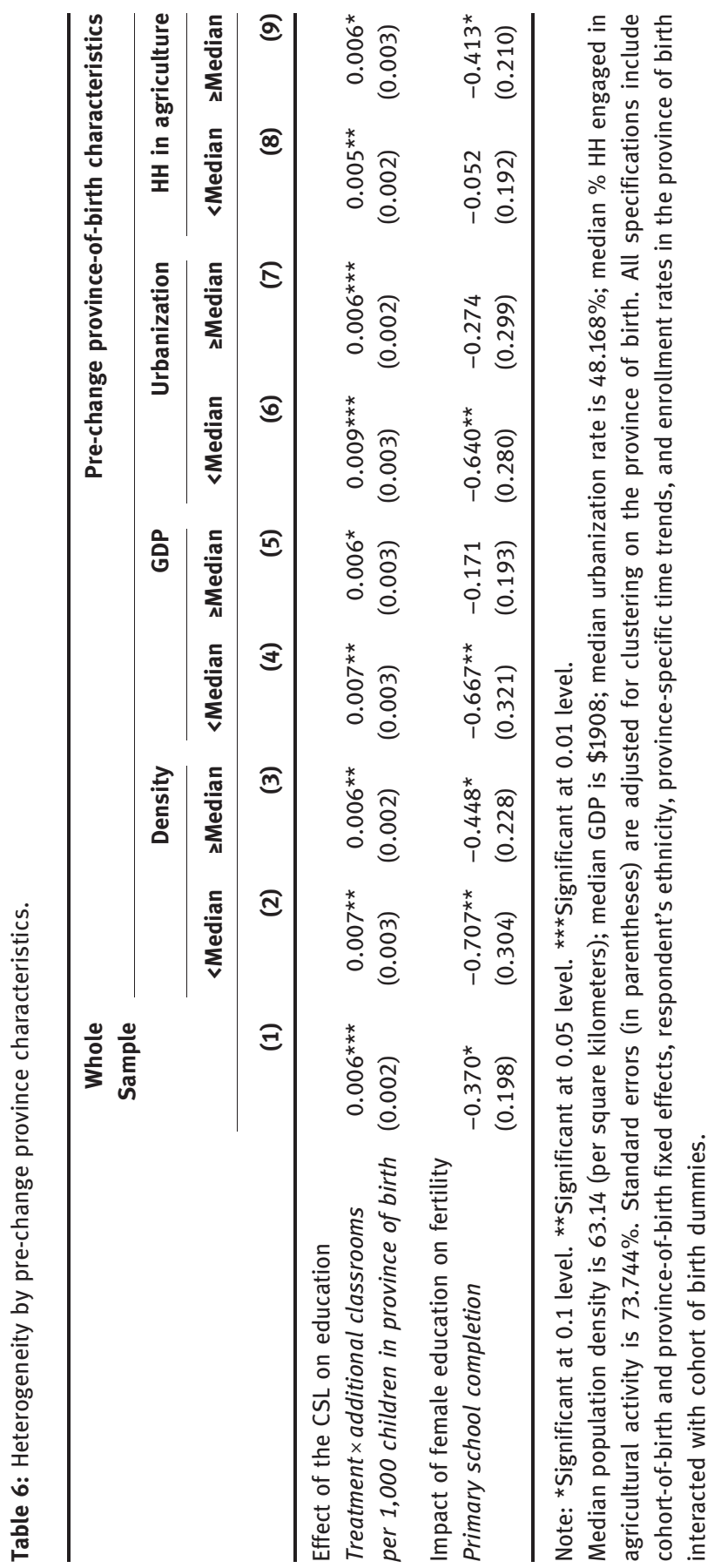


Table 7: Various outcomes.

\begin{tabular}{|c|c|c|c|c|c|}
\hline Panel A: other outcomes & $\begin{array}{r}\text { Probability } \\
\text { of marriage } \\
\text { before } 18\end{array}$ & $\begin{array}{r}\text { Probability } \\
\text { of kids } \\
\text { before } 18\end{array}$ & $\begin{array}{r}\text { Use of } \\
\text { modern } \\
\text { contraceptive }\end{array}$ & $\begin{array}{r}\text { Husband } \\
\text { education }\end{array}$ & \\
\hline OLS & $\begin{array}{l}-0.168^{* \star *} \\
(0.013)\end{array}$ & $\begin{array}{l}-0.081^{\star \star \star} \\
(0.009)\end{array}$ & $\begin{array}{l}0.081^{\star \star \star} \\
(0.021)\end{array}$ & $\begin{array}{l}2.811^{\star \star \star} \\
(0.156)\end{array}$ & \\
\hline $2 S L S$ & $\begin{array}{l}-0.457^{\star \star} \\
(0.188)\end{array}$ & $\begin{array}{l}-0.286^{\star \star} \\
(0.145)\end{array}$ & $\begin{array}{l}0.379^{\star \star} \\
(0.156)\end{array}$ & $\begin{array}{r}1.446 \\
(0.968)\end{array}$ & \\
\hline$p$-value endogeneity test & 0.100 & 0.097 & 0.062 & 0.178 & \\
\hline$p$-value underidentification test & 0.0115 & 0.0026 & 0.0134 & 0.0017 & \\
\hline Observations & 4,537 & 4,537 & 2,600 & 2,596 & \\
\hline Panel B: child health & HAZ & Stunting & WAZ & Underweight & Index \\
\hline OLS & $\begin{array}{l}0.246^{\star \star} \\
(0.100)\end{array}$ & $\begin{array}{l}-0.076^{\star \star \star} \\
(0.023)\end{array}$ & $\begin{array}{l}0.331^{\star \star \star} \\
(0.071)\end{array}$ & $\begin{array}{l}-0.050^{\star \star \star} \\
(0.017)\end{array}$ & $\begin{array}{l}0.181^{\star \star \star} \\
(0.060)\end{array}$ \\
\hline $2 S L S$ & $\begin{array}{c}0.995^{*} \\
(0.559)\end{array}$ & $\begin{array}{l}-0.230^{\star} \\
(0.132)\end{array}$ & $\begin{array}{l}0.901^{\star * *} \\
(0.320)\end{array}$ & $\begin{array}{l}-0.159^{\star} \\
(0.095)\end{array}$ & $\begin{array}{c}0.580^{\star} \\
(0.349)\end{array}$ \\
\hline$p$-value endogeneity test & 0.098 & 0.060 & 0.097 & 0.095 & 0.076 \\
\hline$p$-value underidentification test & 0.0763 & 0.0767 & 0.0783 & 0.0769 & 0.0746 \\
\hline Observations & 1,323 & 1,323 & 1,440 & 1,440 & 1,323 \\
\hline \multicolumn{6}{|l|}{ Control variables } \\
\hline Ethnicity & Yes & Yes & Yes & Yes & Yes \\
\hline Province-specific time trends & Yes & Yes & Yes & Yes & Yes \\
\hline $\begin{array}{l}\text { Cohort of birth } \times \text { enrollment } \\
\text { rate }\end{array}$ & Yes & Yes & Yes & Yes & Yes \\
\hline
\end{tabular}

Note: *Significant at 0.1 level. **Significant at 0.05 level. ${ }^{* *}$ Significant at 0.01 level.

Standard errors (in parentheses) are adjusted for clustering on the province of birth. All specifications include cohort-of-birth and province-of-birth fixed effects.

end, I explore the effect of female education on the probability of having at least one child before age 18 . The results demonstrate that primary school education reduces the probability of having at least one child by 29 percentage points. Because primary school education reduces fertility by 0.37 , the extensive margin represents approximately $97 \%$ of the total effect, implying that the effect of education is almost entirely due to less females becoming mothers. ${ }^{41}$

While female education reduces the probability of becoming a mother, this might be due to a delay in marriage or a delay in childbearing within marriage (childbearing out of wedlock is very rare). Toward this end, I explore the effect of female education on the probability of being married. The results demonstrate that primary school reduces the probability of marriage by 18 by 46 percentage points. Because primary school reduces the probability of childbearing by 29 percentage

41 See online Appendix for calculations. 
points, delayed marriage represents approximately $21 \%$ of the impact of primary school on the probability of childbearing. ${ }^{42}$ Consequently, $79 \%$ of the impact is due to a delay in childbearing within marriage, implying that $76.6 \%$ of the total impact of primary education on fertility is due to a delay in first birth within marriage.

Delving further, delaying childbearing within a marriage might be due to changes in the preferences and constrains of the wife, or that of the husband. While answering this question is challenging, it is possible to explore if female education impacts matching outcomes, specifically the education of their spouse. Uncovering evidence that women with higher education match with husbands with different observable characteristics, attests that the effect of female education on fertility might be attributed, at least in part, to matching outcomes. The results suggest no significant effect on husband education, suggesting, but not ruling out, that matching outcomes are not important.

This paper also explores whether female education impacts contraceptive knowledge and use. There are two primary reasons why female education might be important. First, education might confer knowledge of modern contraceptives (or at least a greater ability to learn about them), or it might result in a shift in attitudes concerning the propriety of contraceptives. Second, changes in contraceptive use might be a reflection of changes in fertility preferences or relative bargaining power in the household. The results suggest that primary school completion increases the use of modern contraceptives.

While child health outcomes might be a cause or a consequence of fertility outcomes, uncovering evidence that female education improves child health demonstrates that there are additional positive spillovers of education. ${ }^{43}$ One limitation is that, among the sample of ever-married women, child health data is only available for 5 years prior to the interview and for the latest born child. Measures of child health include HAZ and WAZ, and the probability of stunting and being underweight. ${ }^{44}$

Moreover, I also construct an index of child health, wherein the four health outcomes are rescaled to map higher values to better child health, and the z-scores are calculated by subtracting the mean of unexposed mothers' children and dividing by the corresponding standard deviation. Following Kling, Liebman, and Katz (2007),

42 See online Appendix for calculations.

43 Specifically, in Becker and Lewis's (1973) quantity-quality model of fertility, child quantity, and quality are jointly determined.

44 Stunting is defined as $\mathrm{HAZ}<-2$ standard deviations, while underweight is defined as $\mathrm{WAZ}<-1$ standard deviations. Underweight is used rather than child malnutrition because less than $1 \%$ of the children in the sample suffer from malnutrition (WAZ $<-2$ ). Approximately $14 \%$ and $12 \%$ of the sample are stunted and underweight, respectively. 
the index is created using an equally weighted average of $z$-scores. The results in Panel B demonstrate that female education significantly improves child health.

\section{Conclusion}

This paper explores the causal relationship between female education and teenage fertility using a change in the CSL in Turkey. I find that the CSL increased primary school completion by approximately 6 percentage points for primary school age females in 1997.

Exploiting variation in schooling generated by the timing of the CSL and variation in the intensity of additional classrooms identifies the causal effect of female education on teenage fertility. The IV estimates suggest that primary school completion reduces teenage fertility by 0.37 births. Moreover, the decline in teenage fertility is particularly acute in provinces with lower population density and higher agricultural activity.

This paper also divides the impact of education on fertility into intensive- and extensive- margin effects, and demonstrates that the effect along the extensive margin is by far the most important. The extensive margin can be further decomposed into effects arising from a delay in marriage and a delay in childbearing within marriage. I find that the most of the effect is due to a delay in childbearing within marriage. This paper also demonstrates that matching outcomes do not appear to be important in the role of education in fertility, while the use of modern contraceptives appears to be important. An important avenue for future research is to examine if these effects are similar for completed fertility. Finally, this paper demonstrates that there are social returns to education beyond reductions in fertility, including improving child health outcomes.

These findings have several important implications for development policy. Improving female education is an important factor for reducing teenage fertility, which in turn is associated with improvements in health, labor market participation, and female empowerment. ${ }^{45}$ Therefore, expanding educational opportunities in countries that currently disempower and disadvantage women, such as Turkey and MENA in general, is an important step in achieving the aims of the UN MDGs. ${ }^{46}$

45 Furthermore, Caceres-Delpiano (2012) show that an increase in fertility has a cost for both children and other household members in developing countries, such as increases in the incidences of unstable family arrangements and the odds of child mortality.

46 Clingingsmith, Khwaja, and Kremer (2009) show that social institutions can foster equality and greater acceptance of female education and employment. Specifically, they show that Hajj leads to more favorable attitudes toward women. 
Moreover, this paper demonstrates that educational interventions are effective in reducing fertility at later stages of the demographic transition, at which point conventional policies for reducing fertility may no longer be effective. Finally, this paper underscores the importance of targeting subpopulations where the impact of expanding educational opportunities have the greatest impact in reducing teenage fertility, such as areas with low income and high agricultural activity.

Acknowledgments: The author thanks to Kenneth L. Leonard for many valuable comments. The author would like to thank Dana C. Andersen, Jere Behrman, Julian Cristia, Linda N. Edwards, Anna Alberini, Vivian Hoffmann, Gheda Temsah, and conference participants at the 2013 NEUDC, the 2012 PACDEV, the 2012 PAA, the 2012 MEA, and the 2012 WEAI for helpful comments. This paper has been significantly improved from the insightful comments of two anonymous referees. The main dataset is provided by Hacettepe University Institute of Population Studies under permission no. 2010-26.

Funding: The author thanks Grand Challenges Canada for the partial support of this study (grant no. 0072-03 to the Grantee The Trustees of the University of Pennsylvania).

\section{Appendix A Descriptive Statistics}

\begin{tabular}{lc}
\hline & Mean \\
\hline Treatment & 0.423 \\
Additional classrooms per 1,000 children in province of birth & 9.44 \\
Female age & 23.64 \\
Female years of completed education & 6.85 \\
Completed 8 or more years of education & 0.46 \\
Fraction of married women & 0.57 \\
Fraction of married women before age 18 & 0.18 \\
Fraction of women having no kids at the time of the survey & 0.52 \\
Fraction of women having no kids before age 18 & 0.93 \\
Number of children ever born & 0.97 \\
Number of children before age 18 & 0.09 \\
Number of children before age 17 & 0.04 \\
Number of children before age 16 & 0.02 \\
Number of observations & 4537 \\
Number of female with children & 2184 \\
\hline
\end{tabular}




\section{References}

Albouy, V., and L. Lequien. 2009. “Does Compulsory Education Lower Mortality?.” Journal of Health Economics 28 (1):155-68.

Angrist, J., and W. Evans. 2000. "Schooling and Labor Market Consequences of the 1970 State Abortion Reforms." Research in Labor Economics 18:75-13.

Barham, T. 2011. "A Healthier Start: The Effect of Conditional Cash Transfers on Neonatal and Infant Mortality in Rural Mexico." Journal of Development Economics 94 (1):74-85.

Becker, G. S. 1981. Treatise on the Family. Cambridge, MA: Harvard University Press.

Becker, G. S., and H. G. Lewis. 1973. "On the Interaction between the Quantity and Quality of Children.” Journal of Political Economy 81:S279-88.

Berger, M., and J. Leigh. 1989. "Schooling, Self Selection, and Health." Journal of Human Resources 24:433-55.

Black, S. E., P. J. Devereux, and K. G. Salvanes. 2008. "Staying in the Classroom and Out of the Maternity Ward? The Effect of Compulsory Schooling Laws on Teenage Births." Economic Journal 118:1025-54.

Bongaarts, J. 2001. Fertility and reproductive preferences in post-transitional societies. Population and Development Review 27:260-81.

Bongaarts, J. 2002. The end of the fertility transition in the developing world. In Completing the Fertility Transition, 288-307. New York: Department of Economic and Social Affairs, Population Division, United Nations.

Borgonovi, F., B. d'Hombres, and B Hoskins. 2010. "Voter Turnout, Information Acquisition and Education: Evidence from 15 European Countries.” The B.E. Journal of Economic Analysis \& Policy 10 (1), Contributions, Article 90.

Breierova, L., and E Duflo. 2004. "The Impact of Education on Fertility and Child Mortality: Do Fathers Really Matter Less than Mothers?.” NBER Working Papers 10513, National Bureau of Economic Research, Inc.

Caceres-Delpiano, J. 2012. "Is There a Cost Associated with an Increase in Family Size Beyond Child Investment? Evidence from Developing Countries." The B.E. Journal of Economic Analysis \& Policy 12 (1), (Advances), Article 17.

Caldwell, J. C. 1980. "Mass Education as a Determinant of the Timing of Fertility Decline." Population and Development Review 6 (2):225-55.

Cameron, A., J. Gelbach, and D. Miller. 2006. "Robust Inference with Multi-way Clustering." NBER Working Papers 327, National Bureau of Economic Research, Inc.

Cameron, C. A., and P. K. Trivedi. 2005. Supplement to Microeconometrics: Methods and Applications. New York: Cambridge University Press.

Cesur, R., B. Dursun, and N. Mocan. 2014. "The Impact of Education on Health and Health Behavior in a Middle-Income, Low-Education Country." NBER Working Papers 20764.

Cesur, R., and N. Mocan. 2013. "Does Secular Education Impact Religiosity, Electoral Participation and the Propensity to Cote for Islamic Parties? Evidence from an Education Reform in a Muslim Country." NBER Working Papers 19769.

Chevalier, A., and T. K. Viitanen. 2003. "The Long-Run Labour Market Consequences of Teenage Motherhood in Britain." Journal of Population Economics 16 (2):323-43.

Clark, D., and H. Royer. 2010. "The Effect of Education on Adult Health and Mortality: Evidence from Britain.” NBER Working Papers 16013, National Bureau of Economic Research, Inc. 
Clingingsmith, D., A. I. Khwaja, and M. Kremer. 2009. "Estimating the Impact of the Hajj: Religion and Tolerance in Islam's Global Gathering." Quarterly Journal of Economics 124 (3):1133-70.

Currie, J., and E. Moretti. 2003. "Mother's Education and the Intergenerational Transmission of Human Capital: Evidence from College Openings." The Quarterly Journal of Economics 118 (4):1495-532.

Cygan-Rehm, K., and M. Maeder. 2013. "The Effect of Education on Fertility: Evidence from a Compulsory Schooling Reform.” Labour Economics 25:35-48.

Dinçer, M. A., N. Kaushal, and M. Grossman. 2014. "Women's Education: Harbinger of Another Spring? Evidence from a Natural Experiment in Turkey." World Development 64:243-58.

de Walque, D. 2007. "Does Education Affect Smoking Behaviors?: Evidence Using the Vietnam Draft as an Instrument for College Education." Journal of Health Economics 26 (5):877-95.

Duflo, E. 2001. "Schooling and Labor Market Consequences of School Construction in Indonesia: Evidence from an Unusual Policy Experiment." American Economic Review 91 (4):795-813.

Dulger, I. 2004. "Turkey: Rapid Coverage for Compulsory Education: The 1997 Basic Education Program." World Bank Conference on "Scaling Up Poverty Reduction: A Global Learning Process", Shanghai.

Fort, M., N. Schneeweis, and R. Winter-Ebmer. 2011. "More Schooling, More Children: Compulsory Schooling Reforms and Fertility in Europe.” IZA Discussion Papers 6015, October 2011.

Fuchs, V. R. 1982. "Time Preference and Health: An Exploratory Study." NBER Chapters, 93-120. National Bureau of Economic Research, Inc.

Geruso, M., D. Clark, and H. Royer. 2011. The Impact of Education on Fertility: Quasi-experimental Evidence from the UK. Mimeo Princeton: Princeton University.

Griliches, Z. 1977. "Estimating the Returns to Schooling: Some Econometric Problems." Econometrica 45 (1):1-22.

Grimard, F., and D. Parent. 2007. "Education and Smoking: Were Vietnam War Draft Avoiders Also More Likely to Avoid Smoking?" Journal of Health Economics 26 (5):896-926.

Güneş, P. M. 2015. "The Role of Maternal Education in Child Health: Evidence from a Compulsory Schooling Law." Economics of Education Review 47:1-16.

Kemptner, D., H. Jürges, and S. Reinhold. 2011. "Changes in Compulsory Schooling and the Causal Effect of Education on Health: Evidence from Germany." Journal of Health Economics 30 (2):340-54.

Kenkel, D., D. Lillard, and A. Mathios. 2006. "The Roles of High School Completion and GED Receipt in Smoking and Obesity." Journal of Labor Economics 24 (3):635-60.

Kirdar, M. G., M. D. Tayfur, and I. Koç. 2012. "The Effect of Compulsory Schooling Laws on Teenage Marriage and Births in Turkey." MPRA Papers 38735.

Kling, J. R., J. B. Liebman, and L. F. Katz. 2007. "Experimental Analysis of Neighborhood Effects." Econometrica 75 (1):83-119.

Lam, D., and S. Duryea. 1999. "Effects of Schooling on Fertility, Labor Supply, and Investments in Children, with Evidence from Brazil." Journal of Human Resources 34 (1):160-92.

Lavy, V., and A Zablotsky. 2011. "Mother's Schooling, Fertility, and Children's Education: Evidence from a Natural Experiment.” NBER Working Papers 16856, March 2011, National Bureau of Economic Research, Inc.

Lindeboom, M., A. Llena-Nozal, and B Van der Klaauw. "Parental Education and Child Health: Evidence from a Schooling Reform." Journal of Health Economics 28 (1):109-31. 
Lleras-Muney, A. 2005. "The Relationship between Education and Adult Mortality in the United States." Review of Economic Studies 72:189-221.

Mason, K. 0. 1986. "The Status of Women: Conceptual and Methodological Debates in Demographic Studies." Sociological Forum 1:284-300.

McCrary, J., and H. Royer. 2011. "The Effect of Female Education on Fertility and Infant Health: Evidence from School Entry Policies Using Exact Date of Birth.” American Economic Review 101:158-95.

Ministry of National Education. 2011. "National Education Statistics Formal Education 2010-2011.” Technical Report, Ankara, Turkey. http://sgb.meb.gov.tr.

Monstad, K., C. Propper, and K. G Salvanes. 2008. "Education and Fertility: Evidence from a Natural Experiment." The Scandinavian Journal of Economics 110:827-52.

Osili, U. O., and B. T Long. 2008. "Does Female Schooling Reduce Fertility? Evidence from Nigeria." Journal of Development Economics 87 (1):57-75.

Rosenzweig, M. R., and T. P Schultz. 1985. "The Demand for and Supply of Births: Fertility and Its Life Cycle Consequences.” American Economic Review 75 (5):992-1015.

Rosenzweig, M. R., and T. P Schultz. 1989. "Schooling, Information and Nonmarket Productivity: Contraceptive Use and Its Effectiveness." International Economic Review 30 (2):457-77.

Schultz, T. P. 1981. Economics of Population. Reading, MA: Addison Wesley.

Schultz, T. P. 1993. "Returns to Women's Education.” In Women's Education in Developing Countries: Barriers, Benefits, and Policies, edited by E. M King, and M. A. Hill. Baltimore, MD: Johns Hopkins University Press (for the World Bank) 48-87.

Sen, A. 1999. Development as Freedom. New York: Knopf.

Silles, M. A. 2009. "The Causal Effect of Education on Health: Evidence from the United Kingdom." Economics of Education Review 28 (1):122-8.

Silles, M. A. 2011. "The Effect of Schooling on Teenage Childbearing: Evidence Using Changes in Compulsory Education Laws.” Journal of Population Economics 24 (2):761-77.

Staiger, D., and J. H. Stock. 1997. "Instrumental Variables Regression with Weak Instruments." Econometrica 65 (3):557-86.

Strauss, J., and D. Thomas. 1995. "Human Resources: Empirical Modeling of Household and Family Decisions.” In Behrman J., Srinivasan T. N., (Eds.), Handbook of Development Economics, vol. 3A, North-Holland Amsterdam 1883-2023.

Thompson, S. 2011. "Simple Formulas for Standard Errors That Cluster by Both Firm and Time." Journal of Financial Economics 99 (1):1-10.

van Kippersluis, H., O. O’Donnell, and E. van Doorslaer. 2011. “Long-Run Returns to Education: Does Schooling Lead to an Extended Old Age?" Journal of Human Resources 46 (4):695-721.

Webbink, D., N. G. Martin, and P. M. Visscher. 2010. "Does Education Reduce the Probability of Being Overweight?” Journal of Health Economics 29 (1):29-38.

Wooldridge, J. 2002. Econometric Analysis of Cross Section and Panel Data. Cambridge: MIT Press. 